\title{
Yayalaştırılmış Bölge Kafeler Caddesi'nin (Isparta) Peyzaj Mimarlığı Açısından İrdelenmesi
}

\author{
Ayça YILDIRIM*, Volkan KÜçÜK²* \\ ORCID 1: 0000-0003-2210-5770 \\ ORCID 2: 0000-0002-8245-1686 \\ ${ }^{1}$ Süleyman Demirel Üniversitesi, Fen Bilimleri Enstitüsü, Peyzaj Mimarlı̆̆ı Ana Bilim Dalı, 32260, Isparta, Türkiye. \\ ${ }^{2}$ Süleyman Demirel Üniversitesi, Mimarlık Fakültesi, Peyzaj Mimarlığı Bölümü, 32260, Isparta, Türkiye. \\ *e-mail:yldrm.ayca.@gmail.com \\ Öz \\ Bu araştırmada, Isparta kent merkezinde yer alan Kafeler Caddesi'nin yayalaştırılmasının peyzaj mimarlığı \\ açııından irdelenmesi amaçlanmıştır. Araştırmanın amacı, yayalaştııılmış Kafeler Caddesinin çevresine olan \\ etkileri, tercih edilme nedenleri, kullanım amaçları, kullanıcıların ihtiyaçlarına ne derecede cevap verebildiği, bu \\ yaya bölgesini kullanan insanların karşılaştığı sorunlar ve planlamasından kaynaklanan genel eksiklikler olarak \\ belirlenmiştir. Ayrıca yaya ve taşıt yolu arasındaki ilişsisi ve yaya aksı üzerindeki perakende ticaret mekânlarına \\ olan etkisi de belirlenmiştir. Bu çalışmada, yaya bölgesi kullanıııları ve işyeri sahiplere yönelik iki farklı anket \\ çalışması uygulanmıştır. 5'li likert ölçeği ile hazırlanan anketler ve elde edilen veriler SPSS programı ile analiz \\ edilmiştir. Elde edilen veriler ışığında araştırma alanının sorunları irdelenmiş ve bu sorunlara yönelik çözüm \\ önerileri sunulmuştur.
}

Anahtar Kelimeler: Yaya, yayalaştırma, yaya bölgesi, yaya trafiği, Isparta, peyzaj mimarlığı.

\section{Investigation of Pedestrianized Kafeler Street (Isparta) in terms of Landscape Architecture}

\begin{abstract}
In this study, it is aimed to examine the pedestrianization of Kafeler Street in Isparta city center in terms of landscape architecture. The purpose of the research, its effects on the environment of pedestrianized cafes, the reasons for its preference, the purposes of use, the extent to which it can respond to the needs of the users, the problems faced by the people using this pedestrian zone and its general deficiencies were determined. In addition, the relationship between pedestrian and vehicle roads and their impact on retail spaces on the pedestrian axis are also determined. In this study, two different surveys were conducted for pedestrian zone users and business owners. Questionnaires prepared with 5-point Likert scale and the data obtained were analyzed with SPSS program. In the light of the data obtained, the problems of the research area were examined and solution suggestions for these problems were presented.
\end{abstract}

Keywords: Pedestrian, pedestrianization, pedestrian zone, pedestrian traffic, Isparta, landscape architecture.

Atıf: Yıldııı, A. ve Küçük, V. (2020). Yayalaştıııımış Bölge Kafeler Caddesi'nin (Isparta) Peyzaj Mimarlığı Açısından İrdelenmesi. Mimarlık Bilimleri ve Uygulamaları Dergisi, 5(1), 81-92.

DOI: $\underline{10.30785 / \mathrm{mbud} .669463}$ 


\section{Giriş}

Yaya ulaşımı dünyadaki ilk ulaşım tipidir. İnsan, var olduğu ilk zamanlarda bir yerden başka bir yere yaya olarak gitmiştir. Atların evcilleştirilmesi ve tekerleğin bulunmasından sonra da at arabalarının ilk kullanıldığı dönemlerden beri ulaşımda yayaları korumak için birçok yöntem geliştirilmiştir. Endüstri Devrimi sonrası sanayileşme ve teknolojik gelişmeler, kırsal alanlardan kentsel alanlara göçe, hızlı kentleşme ve kentlerin plansız gelişmesine ve insan gücünün yerini alacak makine gücünün kullanımına yol açmıştır. Motorlu taşıtların icat edilmesiyle de yaya ulaşımının yerini taşıt ulaşımı almış ve beraberinde farklı ulaşım tiplerinin ortaya çıkmasını sağlamıştır. Otomobil kullanımının artması ile birlikte ulaşım yayalara göre değil neredeyse tamamen motorlu araçlara göre düzenlenmeye başlanmıştır. Yolların daha geniş yapılması sonucunda ise yaya hareketleri kısıtlanmış ve sınırlanmıştır.

Hızlı nüfus artışı ile birlikte taşıt sayısının artması, taşıt yollarının genişlemesine ve yaya yollarında yayaların rahatlığı ve güvenliği konusunda sorunlara yol açmıştır. Bu nedenle, yaya yoğunluğunun en yüksek olduğu yerleşim alanları, alış-veriş merkezleri ve kent merkezlerinin taşıt trafiğinden kısmen ya da tümden arındırılarak, kentteki insanların rahatça kullanabileceği açık alanlar sağlamak kent yaşamı için önemli hale gelmiştir (Gültekin, 2007).

Kentlerde, yaya yolları ve meydanlar, insanların birbirleriyle buluşup bir araya gelecekleri alanlardır. Ancak, araç trafiğinin artmasıyla, yaya yollarının bu işlevleri azalmaktadır. Mevcut yollar, artan sayıda özel otomobilin hareket ve park etme gereksinimlerini karşılayamamakta, kapasiteleri yetersiz kalmaktadır. Araçlar, yaya bölgelerine ve kaldırımlara taşmaktadır. Sonuç olarak, yayalar ve taşıtlar arasında bir karışıklık oluşmaktadır. Bu sorunlar yayaların yanı sıra taşıtları da etkilemektedir. Yayalar ve motorlu araçlar kent merkezlerinde giderek daha fazla alanı paylaştıkça trafik kazaları artmaktadır.

Insan evinde, dış dünyayla olan ilişkilerini çeşitli iletişim olanakları (gazete, kitap, film, video-film, televizyon, telefon vb.) ile sağlayabilmekte ve psiko-sosyal ilişkilerini duyularıyla geliştirebilmektedir. Konut ve çevresi insan ilişkileri açısından önemlidir. Konutlar küçüldükçe, toplumsal yaşam konuttan çıkmakta ve konutta değişen yaşam, zamanla günlük olaylar yoluyla çevreye yansıtılmaktadır. Örneğin çocuklar, erken yaşta oyun alanında oynamak, daha sonra bisiklete binmek ve yaya yolu boyunca yürümek; spor alanlarında vakit geçirmek istemektedir (Kuntay, 1994). Bu durum yayaların mevcut alanları araçlarla birlikte paylaşmasını gerekli kılmaktadır. Ancak bu alanlardaki mevcut düzenlemelerin büyük bölümü araç trafiğine yöneliktir. Yayalara yönelik önemli düzenlemelerden birisi ise yaya bölgeleridir.

\subsection{Yaya Bölgesi Kavramı ve İncelenmesi}

\subsubsection{Yaya kavramı}

Eski çağlarda yayalar yolda yürüyen biri olarak tanımlanırken, günümüzde yaya kaldıımlarını veya kentlerdeki yolları ele geçiren taşıtlar nedeniyle yayalara ayrılmış alanları kullananlar olarak tanımlanmaktadır (Döllük, 2005). Yaya, kentsel alandaki dolaşımı sırasında yürüyerek ya da tekerlekli sandalyeye bağlı engelli bir kişi olması halinde, tekerlekli sandalyesi ile hareket halinde olan ya da dolaşan katılımcıdır (Kaplan ve Acuner, 2005).

\subsubsection{Yayalaştırma}

Yayalaştırma; sadece yaya merkezli ve taşıt ulaşımının kısıtlı olduğu alanlar değil, aynı zamanda yaya yoğunluğunun, hareketlerinin ve faaliyetlerinin iyi gözlemlenmesi sonucu oluşturulan araçların ve insan unsurlarının kontrollü dolaşımının ön plana çıktığı bir ulaşım sisteminin tasarımıdır (Demir, 2008). Yayalaştırma kavramı, şehir planlama ve kentsel tasarım projelerinde trafiksiz yürünülebilir yaya alanları oluşturmak için yapılan müdahaleler olarak da görülmektedir (Döllük, 2005).

Yayalar için bir alan tasarlamak diğer ulaşım sistemlerine göre daha az alan gerektirir, çünkü ulaşım karayoluyla sınırlı değildir. Yayalar için yaya alanları oluşturmak, temel olarak katılımcıların yararınadır. Yayalaştırma, katılımcılara sosyalleşme, estetik memnuniyet, fiziksel ve duygusal sağılı açısından birçok fayda sağlar. Aynı zamanda yaya ulaşımı çevreye en az zarar veren ulaşım tipi olması yönünden de toplum yararı bağlamında önem verilmesi gereken bir konudur (Çalışkan, 2011). 


\subsubsection{Yaya alanı}

Mevcut bina odaklı kentsel mekânda veya planla öngörülen kentsel gelişme mekânında bir ya da birden daha çok yolu barındıran, yaya alanı düzenleme ilkelerine göre müsaade verilen, araç ve bazı durumlar dışında araç trafiğine kapalı, yayaların çeşitli kentsel aktivite, konum ve fonksiyonlara rahatça erişmeleri, dolanımda bulunmaları ve kentsel işlevlerden en iyi şekilde faydalanmalarını sağlamak için düzenlenen kent mekânlarıdır. Bu tanım, alan kullanımının mekân ve zaman boyutlarına göre değerlendirildiğinde aşağıdaki yaya alanı temel sınıflandırılması elde edilir.

- Tam yaya alanı: Taşıt trafiğine tüm mekân ve de zamanda kapalı olan alandır.

- Toplu taşıma akslı yaya alanı: Yayaları desteklemek ve yaya toplu taşıma araçları arasındaki ilişkiyi kurmak için toplu taşıma şeridinin ve toplu taşıma ekipmanlarının yaya alanı ile birlikte düzenlendiği alandır.

- Zaman uyarlı yaya alanı: Bu, genellikle hizmet amaçlı olarak belirli zamanlarda araç trafiğine izin verilen alandır.

- Mekik hizmetli yaya alanı: Yayayı desteklemek amacı ile sadece park et-devam et (park and ride) mekik hizmet taşıtının, park et-devam et park yeri-yaya alanı ilişkisini kurmak amacıyla güzergâh ilkelerine göre araçların girebildiği alandır (Kaplan ve Acuner, 2005).

\subsubsection{Yaya yolu}

13.10.1983 tarihinde kabul edilerek 18.10.1983 yılında 18195 sayılı Resmi Gazete'de yayımlanarak yürürlüğe giren 2918 sayılı Karayolları Trafik Kanunu'nda yer alan 3. maddeye göre yaya yolu kavramı "Yaya yolu (Yaya kaldırımı); Karayolunun, taşıt yolu kenarı ile gerçek veya tüzel kişilere ait mülkler arasında kalan ve yalnız yayaların kullanımına ayrılmıs olan kısmıdır." şeklinde tanımlanmıştır.

Yaya yolları taşıt ve yaya trafiğinin derecelerine bağlı olarak 3 gruba ayrılmaktadır. Bunlar; Taşıt Trafiğine Tümüyle Kapalı Yaya Yolu (Full Mall), Yalnızca Transit Geçişlere İzin Verilen Yaya Yolları (Transit Mall), Taşıt Trafiği İçin Sınırlama Getirilen Yaya Yolu (Semi Mall) (Rubenstein, 1992).

\subsection{Yaya Bölgeleri Düzenleme illkeleri}

\subsubsection{Yaya bölgeleri planlama ilkeleri}

- Yaya yolları amaca yönelik olmalı ve geçişli bir yol sistemi ile yapılandırılmalıdır.

- Yayaların hareket özgürlüğü ve güvenliğine öncelik tanınması gerekir.

- Yaya erişimi önemli ve gerekli bir hareket sistemi oluşturduğundan dolayı öncelik verilmesi gerekir.

- Yaya ulaşımı sadece bir uzaklığın aşııması değil çevrenin duygusal ve ruhsal aşılmasıdır ki, bu da kentliler arasında ulaşımı sağlayan bir öğe olarak düşünülmesi gerekir.

Konutlar ise, yaya yolu planlamasında işlevsel, mekânsal başlangıç noktalarıdır.

Yayaların mesafesiyle ilişkili mekânsal aktivite sınırları ise aşağıdaki gibi belirlenir (Demir, 2008):

- Özel Hedefler (Kişisel alanı ifade eder)

- Kestirim Yol Uzaklığı

- Kestirim Zaman Süresi

- Kişinin Durumu (Yaş-güç-zaman ilişkisi)

- Yolların Sıklığı

- Engeller (Tehlike, iniş, çıkış gibi) 


\subsubsection{Yaya bölgesi tasarım ilkeleri}

- Yaya bölgelerinin ilk işlevleri arasında oturma-dinlenme alanlarının olması yer alır. Konutların yakınındaki okullar, alışveriş merkezleri, bürolar, oyun alanları v.b. bir yaya bölgesi içerisinde yer alabilir.

- Yaya bölgelerinin yayalara ait olduğu tasarım ilkesi vurgulanmalıdır. Yaya bölgesini oluşturan sokakların, bağlandıkları transit yolların kenarlarındaki kaldırım seviyesinde döşenmesi gerekir.

- Yaya bölgelerinin giriş ve çıkışlarına özel düzenlemeler getirilmelidir. Giriş ve çıkışlarına rampa şeklinde alçaltılmış bir kaldırım kenarı düzenlenmesi tercih edilmeli, giriş ve çıkışa özel panolar konulmalıdır.

- Çiçeklikler ya da çitler yaya yolunun kıvrımını belirlemeye yarar. Bu elemanlarla yapılan düzenlemeler yaklaşan taşıt sürücülerinden çocukları saklayacak yapıda olmaması gerekir. Kullanılan bitki yükseklikleri yol kavşaklarında, arabaların kaporta yüksekliği olan 0,75 m'yi geçmemelidir.

- Otoparklarda kullanılacak döşeme diğerlerinden farklılık göstermeli ve böylelikle park edecek araç sürücülerinin görsel olarak park alanını kolayca algılayabilmesi sağlanmalıdır.

- Yaya bölgesi sakinleri için yeterli otopark alanı ve uygun park kolaylığı sağlanmalıdır. Park imkânı olabildiğince yaya bölgesi dışında tutulmalıdır. Otopark isteğinin artış olasıılı̆ı da göz önüne alınmalıdır.

- Taşıt trafiğinin yavaşlamasını sağlayacak düzenlemeleri (tümsek, daralmalar, zikzaklar vb.) ayıran uzaklığın 50m'nin üzerinde olmaması gerekir. Ayrıca bu düzenlemelerin sürücü için de herhangi bir tehlike arz etmemesi gereklidir.

- Taşıtların konutların çok yakınından geçmesini engelleyici düzenlemeler getirilmelidir. Konutlar ile taşıtın geçişine olanak veren yol arasında en az uzaklık 0,60 m olmalıdır.

- Yaya bölgelerinin ışıklandırması yeterli olmalıdır. Armatürler gece karanlığında yeterli ölçütlerde aydınlatacak şekilde planlanmalıdır. $3,5 \mathrm{~m}$ boyunda $25 \mathrm{~m}$ aralıklı direkler idealdir.

- Çocuk oyun alanları zorunlu olarak motorlu trafikten korunmalı ve belirli engellerle ayrılmalıdır.

- Yaya bölgesi giriş-çıkışlarına konulan yaya bölgesini simgeleyen panonun altına "Yaya Bölgesi" yazısı yazılmalıdır.

- Caddenin genişliği yaya bölgesinde çok fazla olmamalıdır. 2,8- 3,2 m genişlik, en büyük arabaların bile yaya bölgelerini oluşturan caddelere girişi için uygundur. Bu genişlik iki bisikletin yan yana geçmesine izin vererek iki arabanın geçişini önler.

- Yaya bölgesinin girişinde, yolların kolayca bulunabilmesi için sokakların isimlerini taşıyan levhalar koyulmalıdır.

- Yaya alanlarında tek yönden kaçınılmalıdır. Çünkü zıt yönden gelen araçları hesaba katmazlarsa, araçların hızları artabilir.

- Yaya bölgesindeki önemli konulardan biri sağlam ve uygun bir altyapıya sahip olduktan sonra plan yapmaktır. Bunun için otopark alanlarını ve ağaç dikme alanlarını belirlemek gerekir.

- Yaya Bölgeleri düzenlemesi, araç trafiğinin yoğunluğuyla ilgilidir ve planlamada da göz önünde bulundurulmalıdır (Demir, 2008).

\subsubsection{Yaya bölgelerinin tarihsel gelişimi}

Eski zamanlarda, sokaklar ve meydanlar, insanların bir araya gelerek, çeşitli sosyal, kültürel ve ticari faaliyetler düzenlediği şehirlerin en hareketli yerleriydi. Halkın toplandığı bu alanlara 'agora' ve 'forum' denilmiştir (Aru, 1965; Şenkaynak, 2010). 
Almanya, Avrupa'da yayalaştırma çalışmalarında önde gelen ülkelerden biri olup bunda II. Dünya Savaşı'nın kent üzerindeki etkisi büyük olmuştur. Özellikle tarihi binaların restorasyonu ve korunması fikriyle, Batı Almanya'daki şehrin yeniden inşası projelerinde yayalara geçiş yapılmıştır (Robertson, 1994).

Türkiye'de yaya bölgeleri konusu ilk olarak 1955 yılında İstanbul'da düzenlenen "Uluslararası yollar Kongresi"nde tartışıldı. Uygulanacak olan ilk çalışma, Ankara Belediyesi tarafından 1978 yılında Yüksel, İzmir ve Sakarya sokaklarında Kızılay ve Yenikent semtlerinde başlatılan yayalaştırma çalışmaları olmuştur (Zafer, 1998; Gültekin, 2008).

\section{MATERYAL VE YÖNTEM}

\subsection{Materyal}

Araştırmanın ana materyalini Isparta kent merkezinde yer alan Kutlubey Mahallesinde bulunan ve halk tarafından "Kafeler Caddesi" olarak adlandırılan bölge ve bu yaya bölgesinin kullanıcısı olan kent halkı ile işyeri sahipleri oluşturmaktadır. Bu alanın seçilmesinin nedeni yaya faaliyetlerinin yoğunlaştığı bir odak noktası olmasıdır.

\subsubsection{Araştırma yerinin özellikleri}

\subsubsection{Isparta ilinin genel konumu}

Isparta ili, Akdeniz Bölgesi'nin Antalya Bölümü’nün kuzeyinde Göller Yöresi'nin merkezi konumunda

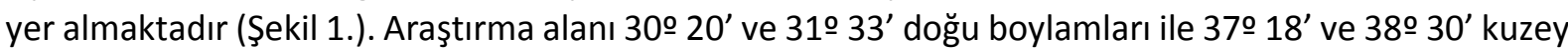
enlemleri arasında yer almaktadır. Kuzeyi ve batısında Afyon ili, kuzeydoğu, doğu ve güneydoğusunda Konya ili; güneyinde Antalya ili, batı ve güney batısında ise Burdur ili ile çevrilidir. Araştırmaya konu olan Isparta ilinde 13 ilçe, bu ilçelere bağlı 38 belde ve 173 köy bulunmakta olup toplam yüzölçümü $8933 \mathrm{~km}^{2 \prime}$ dir (Yıldız, 2011).

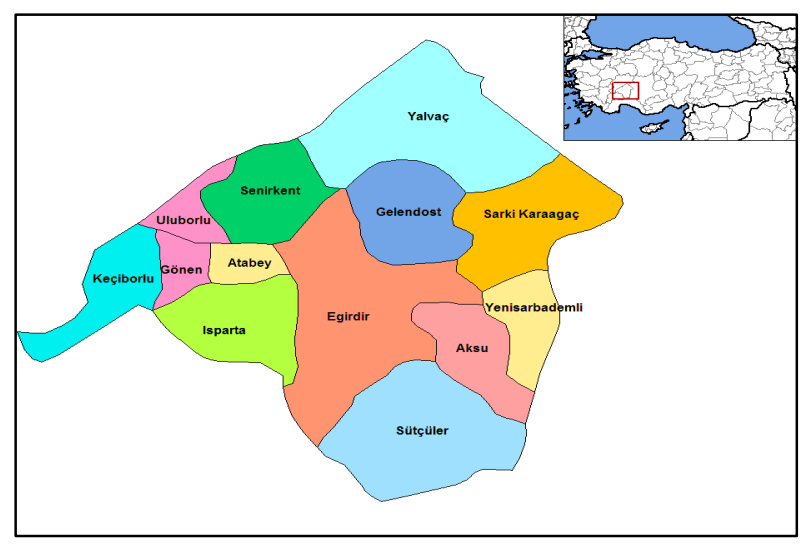

Şekil 1. Isparta ilinin konumu

\subsubsection{2. Çalışma Alanının Mevcut Durumuna Yönelik Değerlendirmeler}

\subsection{Ulaşım}

Çalışma alanı kent merkezinde yer aldığından kullanıcılar tarafından ulaşım zorluğu yaşanmamaktadır. Kent merkezi ve çevresinden servis araçları ile ulaşım sağlanabilmektedir. Yayalar yaya ulaşımını tercih ederken iş yeri sahipleri özel araçları ile ulaşımı tercih etmektedir (Şekil 2.-3.- 4.-5.-6.). 


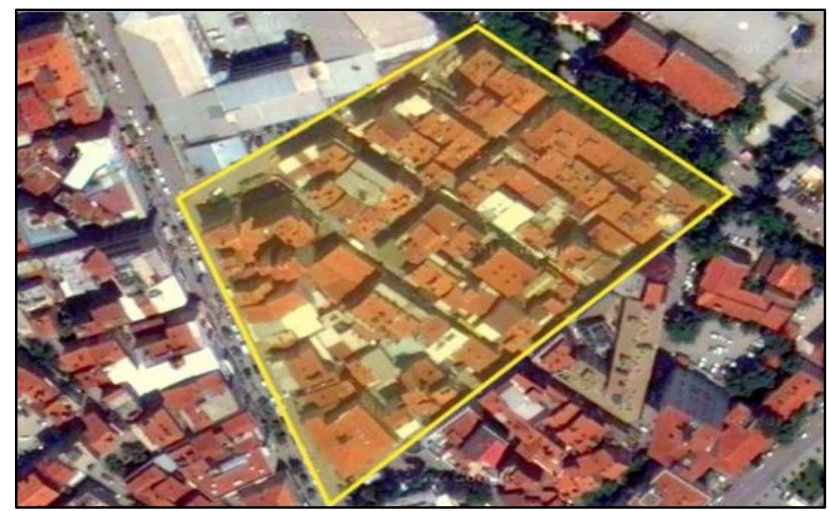

Şekil 2. Çalışma alanının konumu

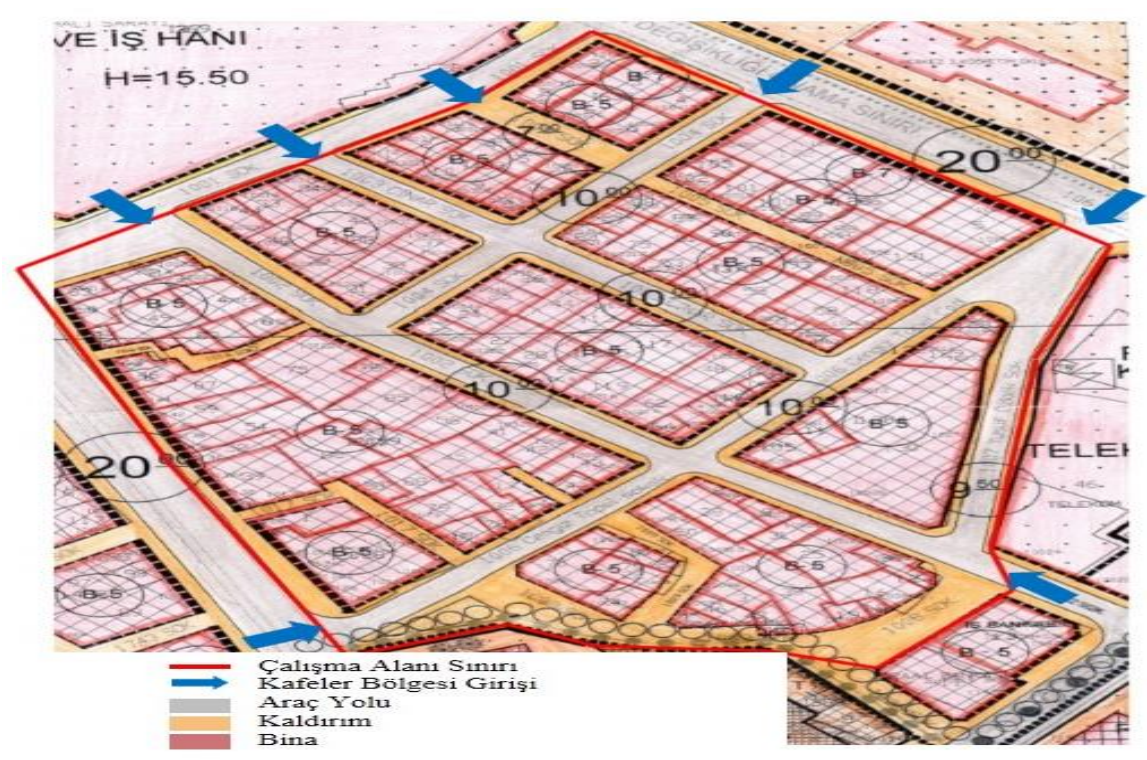

Şekil 3. Kafeler bölgesi ulaşım durumu

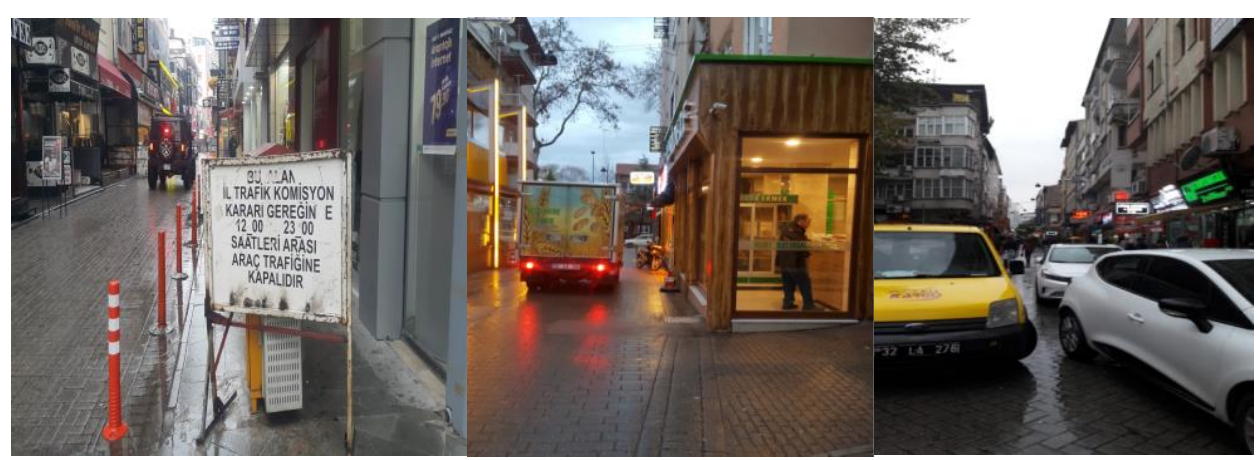

Şekil 4. İzin verilen saatlerin dışında görülen bir araçlar (Orijinal, 2018)

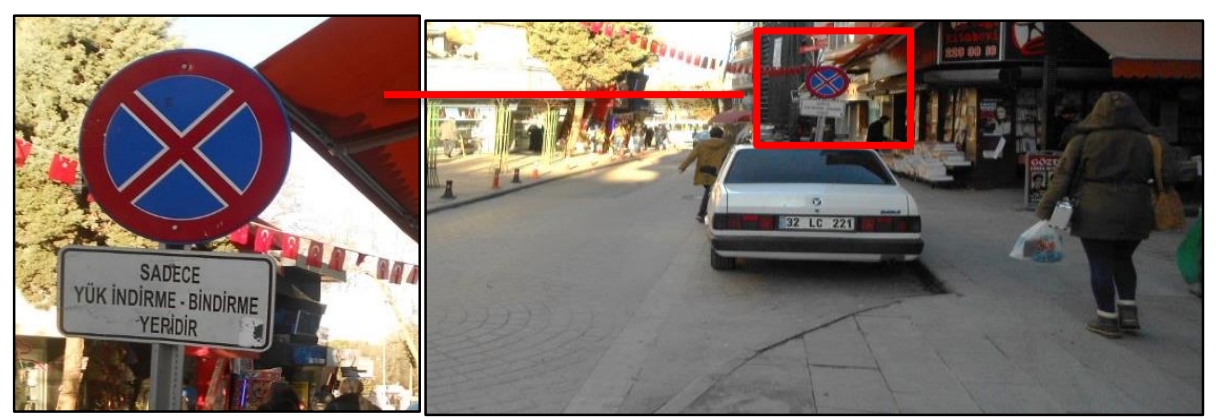

Şekil 15. Yük indirme-bindirme yerine park edilen bir araç (Orijinal, 2018) 

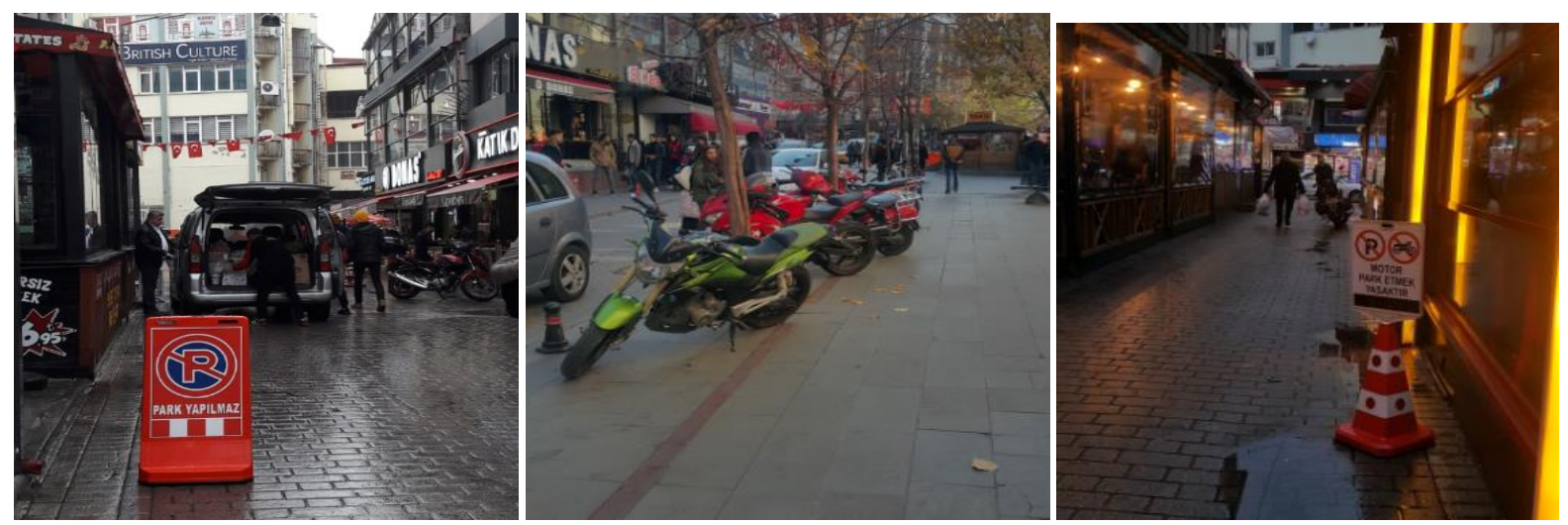

Şekil 6. Uygun olmayan yerlere park edilen bisiklet ve motosikletler (Orijinal,2018)

\subsection{Yapı}

Çalışma alanı yayalar tarafından alışveriş, yeme-içme, dinlenme ya da geçiş alanı olarak kullanılmaktadır. Alanda beş katlı binalar bulunmakta olup zemin katlarında kırtasiye, yeme-içme, alışveriş, giyim, bijuteriye yönelik çok sayıda dükkân bulunmaktadır. Binalara ait cephe siluetleri uyum içinde olup birbirini tamamlar niteliktedir. Sokaklara ait zemin döşemesi alan boyunca aynı olup sokaklardan ana caddeye bağlanan kısımlara kadar devam etmektedir (Şekil 7.).

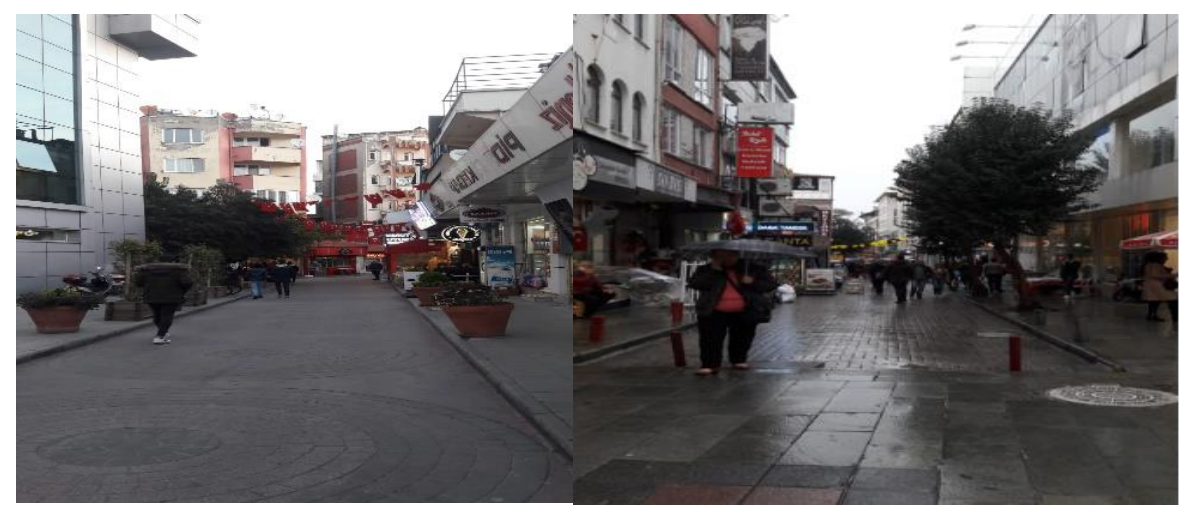

Şekil 7. Cadde sokak bağlantıları (Orijinal, 2018)

\subsection{Donatı elemanları}

Çalışma alanındaki donatı elemanları değerlendirildiğinde aydınlatma elemanlarının ve oturma birimlerinin yeterli sayıda ve çevresi ile uyumlu olduğu gözlemlenmiştir. Oturma birimleri 1008 ve 1001 Sokak'ta ki toplanma alanında bulunmaktadır (Şekil 8.).

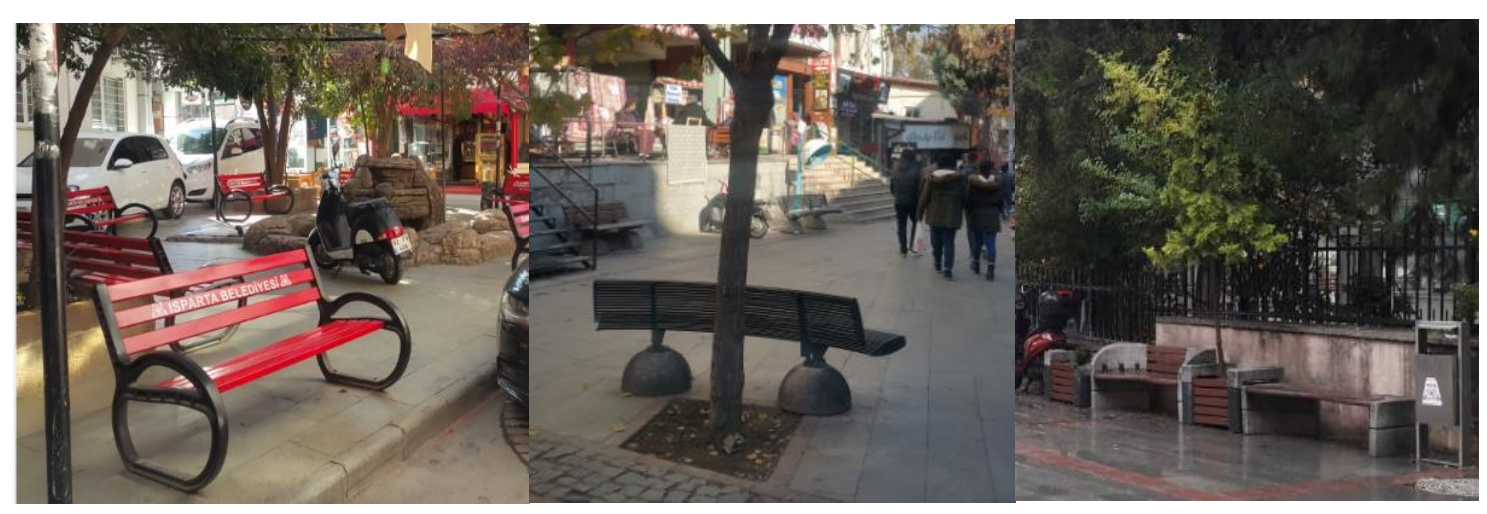

Şekil 8. Aydınlatma elemanı ve toplanma alanlarındaki oturma birimleri (Orijinal, 2018) 


\subsection{Bitkisel doku}

Çalışma alanında bitkisel doku oldukça azdır. 1006. Sokak ve 1008. Sokak'ta Prunus laurocerasus (Karayemiş) bitkisi ve bitki kasaları bulunmaktadır. Yerleştirilen bitki kasaları çevresi ile uyum sağlamaktadır. Ancak bazı bitki kasalarının gelişi güzel yerleştirilmesi bitkinin yeterli güneş ışığı almasını engellemektedir (Şekil 9.).

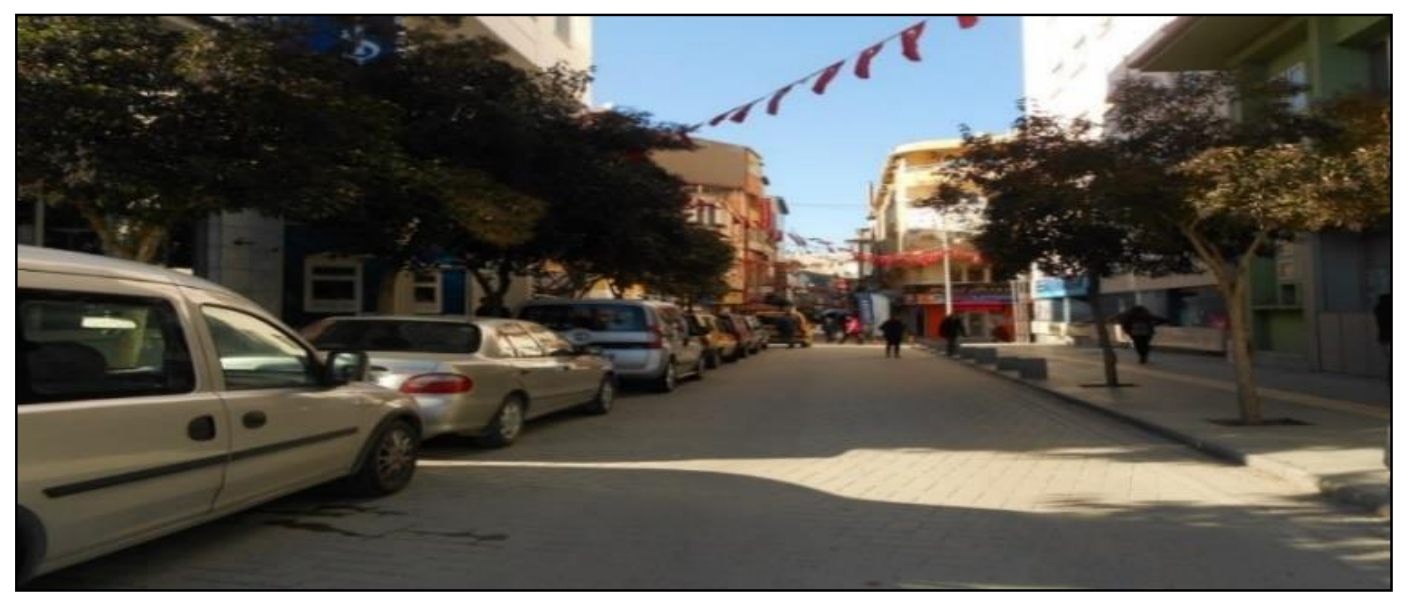

Şekil 9. 1008. Sokak'taki bitkisel düzenleme (Prunus laurocerasus) (Orijinal, 2018)

\subsection{Yöntem}

Araştırmada kullanııların alan kullanım algılarını, tercihlerini, ihtiyaçlarını belirlemek, mekanı nasıl değerlendirdiklerini yorumlamak ve memnuniyetlerini ölçmek için anket yöntemi uygulanmıştır. Araştırma kapsamında kent halkı ve Kafeler Caddesi'ndeki işyeri sahipleri ile olmak üzere iki farklı anket çalışması yapılmıştır. Her iki grup içinde iki farklı anket formu hazırlanmış ve anketler yüz yüze yapılmıştır. Anketlerde demografik özelliklere yönelik sorularla algı, memnuniyet ve kullanım özelliklerine yönelik sorular bulunmakta olup, değerlendirme için $5^{\prime} l i$ likert ölçeği kullanılmıştır. Anketlerin sayısallaştırılmasında Microsoft Office Word ve Microsoft Office Excel programları, elde edilen verilerin değerlendirilmesi için SPSS v25 istatistik paket programı kullanılmış elde edilen bulgular ise ilgili literatür yardımı ile tartışılarak çalışma sonuçlandırılmıştır.

\section{ARAŞTIRMA BULGULARI}

\subsection{Halka Ait Peyzaj Mimarlığı Anketi Bulgularının İncelenmesi}

\subsubsection{Araştırmada yer alan halka ait demografik bulgular}

Araştırmaya katılanların \%44,60'ı kadın, \%55,40'ı ise erkektir. Araştırmaya katılanların \%6'sı 14-17 yaş gurubunda, $\% 68,20$ 'si 18-25 yaş grubunda, 26-35 yaş grubundakilerin oranı \%17,60, 36-45 yaş grubundakilerin oranı $\% 4,8$ ve 46 yaş ve üzerindekilerin oranı $\% 3,4$ olarak görülmektedir. Araştırmaya katılanların \%0,60'ı okur-yazar değil ve ilköğretim mezunu, \%11,60'ı lise mezunu, lisans mezunlarının oranı $\% 76,70$, Yüksek lisans mezunu olanların oranı $\% 7,40$ ve doktorasını tamamlamış olanların oranı $\% 3,10$ 'dur. Katılımcıların \%63,60'ını öğrenciler oluştururken geri kalan meslekleri yapan en fazla, $\% 8,80^{\prime} i$ Mimar-Mühendis, \%4,80'i öğretmen akademisyen, \%3,40'ı işsiz ve \%4'ü de memurlardan oluşmaktadır. Yaşanılan bölgede süre dağılımına bakıldığında ise 1 yıldan az yaşayanların oranı \%6, 1-5 yıl arası yaşayanların oranı \%50, 6-10 yıl arası yaşayanların oranı \%15,60, 11-20 yıl arası yaşayanların oranı $\% 15,60$ ve 21 yıl veya daha fazla olanların oranı \%12,80'dir. Katılımcıların gelir düzeyleri açısından bakıldığında 2.000TL'den az geliri olanların \%68,50, 2.001-3.000 TL arasında geliri olanların \%13,60, 3.001-4.000 TL arasında geliri olanların oranı \%6,80, 4.001-5.000 TL arasında geliri olanların oranı $\% 5,70$ ve 5.001 TL üzerinde geliri olanların oranı ise \%5,40'tır. Araştırmada katılımcıların kafeler caddesi kullanımlarına ilişkin seçenekler sunulmuştur. Kullanımlarına göre bakıldığında katılımcıların en fazla \%69 oranla haftada bir veya birkaç kez uğradığı, \%21,90'ı ise günde bir veya birkaç kez uğradığını belirtmektedir. Ulaşıma yönelik kullanıma bakıldığında \%42,60'ı toplu taşıma tercih etmekte, \%21,30'u özel araç kullanmakta, belirli bir kesim \%7,40'ı seyahat edilen yerlere bisiklet-motosiklet ulaşımı 
sağlamakta ve $\% 28,70$ 'i yaya ulaşımı ile kısa mesafe veya uzun mesafe ayırt etmeksizin kullandığını belirtmiştir.

\subsubsection{Halkın görüşlerinin peyzaj mimarlığı açısından incelenmesine yönelik dikkate alınması gereken faktörler}

Araştırmada halk görüşlerinin peyzaj mimarlığı açısından incelenmesine yönelik dikkate alınması gereken faktörlerin ne olması gerektiği ile ilgili olarak 14 ifadeden oluşan bir gösterge listesi halk grubunun değerlendirmesine sunulmuş ve halk grubundan bu ifadeleri en önemli gördükleri ifadeye 5 , en önemsiz gördükleri ifadeye 1 puan vermek sureti ile puanlamaları istenmiştir. Yapılan bu değerlendirmeye göre en yüksek puan alan ifadeden en az puan alan ifadeye doğru bir sıralama yapılmış ve Çizelge 1 'de verilmiştir.

Çizelge 1 incelendiğinde bireylere sunulan faktörlerin hepsinin ortalaması 2.5 değerinin üzerinden puanlamaya tabi tutulmuştur. Bu durumda bireylere sunulan tüm bu soruların yaşam kalitesini açıklayıcı önemli noktaların bulunduğunu ve yansıttığını göstermektedir. Çizelge daha kapsamlı incelendiğinde "Kafeler Bölgesi içine araçların girmesi beni rahatsız ediyor." ifadesinin 4,32 puanla en yüksek değeri aldığı görülmektedir.

Çalışma ile elde edilen bu bulgular peyzaj açısından ayrılacak bireylerin, çevre düzenine anlamlı ölçüt bulup bulmadığının büyük önemini göstermektedir.

Çizelge 1. Alan kullanııılarının peyzaj mimarlığı açııından dikkate aldıkları ifadeler

\begin{tabular}{|c|c|c|c|}
\hline ifadeler & Ort. & $\begin{array}{l}\text { Std. } \\
\text { Sap. }\end{array}$ & Var. \\
\hline İfade 1 Kafeler Bölgesi içine araçların girmesi beni rahatsız ediyor. & 4,32 & 1,041 & 1,085 \\
\hline İfade 9 Kafeler Bölgesi'nde bitkisel düzenlemeler yetersizdir. & 4,16 & 1,076 & 1,158 \\
\hline İfade 4 Kafeler Bölgesi'nde güvenlik birimlerine yer verilmelidir. & 4,10 & 1,105 & 1,221 \\
\hline $\begin{array}{l}\text { İfade } 3 \text { Kafeler Bölgesi'nde acil ihtiyaçlar için kısa süreli, cep otopark uygulamas } \\
\text { olmalıdır. }\end{array}$ & & 1,310 & 1,716 \\
\hline İfade 10 Kafeler Bölgesi'nde yeteri kadar gölgeleme elemanı yoktur. & 3,55 & 1,095 & 1,200 \\
\hline İfade 2 Kafeler Bölgesi'nde park sorunu yaşıyorum. & 3,29 & 1,508 & 2,275 \\
\hline $\begin{array}{l}\text { İfade } 11 \text { Kafeler Bölgesi'nde kullanılan yer döşemeleri yaya bölgesinde olduğumu } \\
\text { hissettiriyor. }\end{array}$ & & 1,205 & 1,451 \\
\hline $\begin{array}{l}\text { İfade } 8 \text { Kent mobilyaları (çöp kutuları, çiçeklikler, bisiklet park yerleri, sokak lambaları, } \\
\text { çeşme vb.) ve diğer yapısal elemanlar kırık/zarar görmüş olduğu için kullanmakta } \\
\text { zorlanıyorum. }\end{array}$ & & 1,194 & 1,425 \\
\hline İfade 6 Kafeler Bölgesinde akşam saatlerinde aydınlatma yeterlidir değildir. & 3,13 & 1,157 & 1,339 \\
\hline $\begin{array}{l}\text { İfade } 12 \text { Kafeler Bölgesi'nde kullanılan yer döşemeleri kırık/zarar görmüş olduğu için } \\
\text { yürümekte zorlanıyorum. }\end{array}$ & & 1,220 & 1,489 \\
\hline $\begin{array}{l}\text { İfade } 13 \text { Kafeler Bölgesi çevresinde rahatsız edici hava kirliliği, gürültü, koku vb. olduğu } \\
\text { için vakit geçirmiyorum. }\end{array}$ & & 1,413 & 1,996 \\
\hline İfade 5 Kafeler Bölgesi'ni akşam kullanmak güvenli değildir. & 2,94 & 1,298 & 1,686 \\
\hline Ifade 7 Kafeler Bölgesi'nde ki oturma birimleri yeterlidir de & 2,86 & 1,272 & 1,619 \\
\hline İfade 14 Kafeler Bölgesi'nde c & 2,41 & 1,444 & 1,996 \\
\hline
\end{tabular}

N:352; Var: Varyans; Ort: Ortalama; Std. Sap: Standart Sapma

Çizelge 1 incelendiğinde sonrasında gelen 4,16, 4,10 ve 3,74 ortalama puanla "Kafeler Bölgesi'nde bitkisel düzenlemeler yetersizdir, Kafeler Bölgesi'nde güvenlik birimlerine yer verilmelidir ve Kafeler Bölgesi'nde acil ihtiyaçlar için kısa süreli, cep otopark uygulaması olmalıdır" ifadeleri oluşturmaktadır.

\subsection{Esnafa Ait Peyzaj Mimarlığı Anketi Bulgularının İncelenmesi}

\subsubsection{Araştırmada yer alan esnafa ait demografik bulgular}

Araştırmaya katılan esnafın cinsiyet, yaş, eğitim, meslek, gelir durumları, iş yerlerine ait sorular ve faaliyet süresine vb. ilişkin frekans ve yüzde değerleri bu başlık altında gösterilmiştir. Buna göre; Araştırmaya katılanların \%22'si kadın, \%78'i ise erkektir. Araştırmaya katılanların \%28,80'i 18-25 yaş grubunda, 26-35 yaş grubundakilerin oranı $\% 44,00,36-45$ yaş grubundakilerin oranı $\% 21,6,46-55$ yaş grubundakilerin oranı $\% 2,4,56$ yaş ve 
üzerindekilerin oranı ise $\% 2,4$ olarak görülmektedir. Araştırmaya katılanların \%0,60'ı okur-yazar değil ve ilköğretim mezunu, \%11,60' । lise mezunu, lisans mezunlarının oranı \%76,70, Yüksek lisans mezunu olanların oranı $\% 7,40$ ve doktorasını tamamlamış olanların oranı \%3,10 olarak bulunmuştur. Katılımcıların gelir düzeylerine bakıldığında 2.001-3.000 TL arasında geliri olanların oranı \%22,00, 3.001-4.000 TL arasında geliri olanların oranı $\% 26,80,4.001-5.000 \mathrm{TL}$ arasında geliri olanların oranı \%29,30 ve 5.001 TL üzerinde geliri olanların oranı ise \%22,00'dır. Esnafların yüksek oranda 4.001-5.000 TL düzeyinde gelire sahip olduğu görülmektedir. Yaşanılan bölgede mesleki faaliyet kolu dağılımına bakıldığında ise hizmet oranı \%61, imalat oranı \%2,4, ticaret oranı \%29,30 ve ulaşım oranı ise \%7,30 olarak görülmektedir. Esnaf dağılımlarının büyük çoğunluğunda mesleki faaliyetleri hizmet olarak yansıdığı görülmektedir. Esnafların faaliyetlerini devam ettirdiği süre dağılımına bakıldığında 1 yıldan az faaliyet gösterenlerin oranı \%22, 1-5 yıl arası faaliyet gösterenlerin oranı \%43,80, 6-10 yıl arası faaliyet gösterenlerin oranı \%19,50, 11-20 yıl arası faaliyet gösterenlerin oranı \%9,80 ve 21 yıl veya daha fazla faaliyet gösterenlerin oranı \%4,90 olarak görülmektedir.

Esnafların iş yerine mal taşınırken kamyon kullanmasının oranı \%7,30’u, \%29,30’u kamyonet kullanırken, sadece insan gücüyle çalışan işletmelerde $\% 24,40$ 'ı, kendi araçları ve şirket aracıyla birlikte otomobil kullanan esnafın oranı ise \%39 olarak görülmektedir. Araştırmada esnafın kafeler caddesinde iş yerlerine mal getirme süresine yönelik kullanımlarına ilişkin seçenekler sunulmuştur. Kullanımlarına göre bakıldığında katılımcıların en fazla \%51,20 oranla on beş günde bir kez taşınmakta olduğunu, sonrasında ise en fazla \%31,70 yüksek oranla ise günde bir veya birkaç kez mal taşındığını belirtmektedir. Ulaşıma yönelik kullanımda esnafın kafeler caddesine ulaşımlarını özel araç kullanarak yapma durumunda \%43,90 oranında evet, \%56,10 oranında hayır cevabı alınmıştır. Esnafın işyerlerine yakın otopark kullanımda kafeler caddesine uzak olmadan yakınlarındaki otopark durumuna $\% 90,20$ oranında evet cevabı verilirken, \%9,8 oranında esnaf otopark uzak olmasından şikayetçi olmaktadır.

Araştırmada esnafın kafeler caddesinde iş yerlerine yakın yere park etmek istemelerine yönelik kullanımlarına ilişkin seçenekler verilmektedir. Kullanımlarına göre bakıldığında katılımcıların en fazla \%68,40 oranla otoparka park etmekte olduğunu, genelde cadde üzeri kullanımını zorunda kalmadıkça ve az tercih ettiklerini \%31,60 oranında belirtmektedir.

Çalışma ortamlarından memnun olma durumlarına baktı̆̆ımızda esnafın büyük çoğunluğu kafeler caddesinde memnun bir çalışma ortamında olduklarını \%80,50 oranında evet, memnun olmayan esnafa yönelik cevapların ise \%19,50 oranında hayır olarak yanıtlamış oldukları görülmektedir. Esnafa ait kafeler caddesine toptancı giriş çıkış durumunda sorun olarak gören esnafa baktığımızda, esnafın büyük çoğunluğu kafeler caddesinde bu durumu sorun olarak gördüklerini \%65,90 oranında evet cevabıyla verirken, bu durumu sorun olarak görmeyen ve memnun olan esnafa yönelik cevapların ise $\% 34,10$ oranında hayır olarak yanıtlamış oldukları görülmektedir.

\subsubsection{Esnafa yönelik görüşlerin peyzaj mimarlığı açısından incelenmesinde dikkate alınması gereken faktörler}

Araştırmada esnaf görüşlerinin peyzaj mimarlığı açısından incelenmesine yönelik dikkate alınması gereken faktörlerin ne olması gerektiği ile ilgili olarak 8 ifadeden oluşan liste esnaf grubunun değerlendirmesine sunulmuş ve esnaftan bu ifadeleri en önemli gördükleri ifadeye 5, en önemsiz gördükleri ifadeye 1 puan vermek sureti ile puanlamaları istenmiştir. Yapılan bu değerlendirmeye göre en yüksek puan alan ifadeden en az puan alan ifadeye doğru bir sıralama yapılmış ve Çizelge 2'de verilmiştir.

Çizelge 2 incelendiğinde bireylere sunulan faktörlerin hepsinin ortalaması 2.5 değerinin üzerinden puanlamaya tabi tutulmuştur. Bu durumda bireylere sunulan tüm bu soruların peyzaj açısından kaliteli ve sürdürülebilir alanların oluşumunda açıklayıcı önemli noktaların bulunduğunu ve yansıttığını göstermektedir. Çizelge daha kapsamlı incelendiğinde "Kafeler Bölgesi'nde yapılacak olan yeni peyzaj düzenlemelerinin işlerinizi olumlu etkiler." ifadesinin 3,95 puanla en yüksek değeri aldığı görülmektedir. Çalışma ile elde edilen bu bulgular peyzaj açısından ayrılacak esnafın, çevre düzenine anlamlı ölçüt olduğunun büyük önemini göstermektedir. 
Çizelge 2. İs yeri sahiplerinin peyzaj mimarlığı açısından dikkate aldıkları ifadeler

\begin{tabular}{|c|c|c|c|}
\hline ifadeler & Ort. & $\begin{array}{l}\text { Std. } \\
\text { Sap. }\end{array}$ & Var. \\
\hline $\begin{array}{l}\text { İfade } 3 \text { Kafeler Bölgesi'nde yapılacak olan yeni peyzaj düzenlemeleri işlerinizi olumlu } \\
\text { etkiler. }\end{array}$ & 3,95 & 1,264 & 1,598 \\
\hline İfade 1 Kafeler Bölgesi'nin trafiğe kapatılması işlerinizi olumlu etkiledi. & 3,80 & 1,145 & 1,311 \\
\hline İfade 2 Kafeler Bölgesi'nde ki peyzaj düzenlemeleri işlerinizi olumlu etkiliyor. & 3,37 & 1,392 & 1,938 \\
\hline İfade 8 Kafeler Bölgesi'nde güvenlik yeterlidir. & 3,24 & 1,319 & 1,739 \\
\hline Ifade 4 Akşam saatlerinde aydınlatma yeterlidir. & 2,80 & 1,382 & 1,911 \\
\hline Iffade 7 Engelli bireyler işyerime giriş/çııısta sıkıntı yaşamıyor. & 2,76 & 1,445 & 2,089 \\
\hline İfade 6 Kafeler Bölgesi'nde ki zemin döşemeler yeterlidir/düzgündür. & 2,66 & 1,353 & 1,830 \\
\hline İfade 5 Kafeler Bölgesi trafiğe açılmalıdır. & 2,54 & 1,450 & 2,102 \\
\hline
\end{tabular}

N:41; Var: Varyans; Ort: Ortalama; Std. Sap: Standart Sapma

\section{Sonuç ve Öneriler}

Anket çalışmasının sonuçlarına göre alan kullanıcıları taşıt trafiğinin cadde dışına taşınmasını istemektedirler. Bu durum karşısında kent bütününde sürdürülebilir planlama yaklaşımı ile yaya ve bisiklet kullanımı teşvik edilerek taşıt kullanımını azaltıcı çözümler getirilmesi büyük önem taşımaktadır. Yaya bölgeleri girişlerine yakın noktalarda, yeterli büyüklükte ve sayıda otoparklar planlanmalıdır. Ayrıca bu alanlar bisiklet yolları ile bütünleştirilmelidir. Araştırma alanında gerek donatı ve malzemelerin uyumu gerekse kullanıcıların alanda rahatça dolaşımlarını engelleyen uygulamalar ile bazı düzenlemeler iyileştirilmelidir.

Yaya bölgesine belli ve sınırı saatlerde sadece servis girişlerine izin verilmelidir. Bunun yanı sıra alana acil durumlarda girişler için (ambulans, yangın araçları vb.) güvenlik planlamaları ve hazırlıkları da yapılmalıdır. Alan ve yakın çevresinden yaya ulaşılabilirliği ve konforu temel alınmalı, erişim mesafesi yayayı yormayacak şekilde en kısa mesafeden düzenlenmeli, yayayı yönlendirecek alan düzenlemelerine gidilmesi esas alınmalıdır. Engellilere yönelik mekân giriş çıkı̧ları standartlara uygun bir şekilde düzenlenmeli ve engelli bireyler için alan içi erişim kolaylığı sağlanmalıdır. Alanda engellilerin rahat hareket edebileceği ve çeşitli aktivitelerden yararlanabileceği düzenlemeler yapılmalıdır. Planlama yapılırken sürdürülebilir yaşam odaklı planlama içerisinde yayaya ve yaya güvenliğine önem veren planlama kararları verilmelidir. Yayalaştırma çalışmaları bu planlama anlayışı içerisinde uygulanmalıdır. Alanda yapılacak planlama ve tasarımlar için alanın mevcut mekânsal yapısının ve yayaların hareket kompozisyonunun birlikte değerlendirilmesi gerekliliği ortaya çıkmaktadır. Yaya ulaşımı, konforu ve güvenliği için öncelikle var olan yanlışların giderilmesi gerekmektedir. Çalışma alanındaki kullanımlarda alan kullanıııarının ve iş yeri sahiplerinin duyarlı olması Kafeler Bölgesi'ni herkes için daha kullanışlı ve konforlu hale getirecektir.

\section{Teşekkür ve Bilgi Notu}

Bu araştırmada, Isparta kent merkezinde yer alan Kafeler Caddesi'nin yayalaştırılmasının peyzaj mimarlığı açısından incelenmesi amaçlanmıştır. Yayalaştırılmış bölge olan Kafeler Caddesi'nde planlama ve tasarımın ne derecede başarılı olduğu, bu yaya bölgesinin kentsel planlama ile ilişkili olarak öneminin belirlenmesine katkı sağlayan bu makale; Süleyman Demirel Üniversitesi, Fen Bilimleri Enstitüsü, Peyzaj Mimarlığı Ana Bilim Dalı’nda yüksek lisans tezi olarak ele alınan; "Yayalaştırılmış Bölge "Kafeler Caddesi" (Isparta'nın) Peyzaj Mimarlığı Açısından İrdelenmesi" adlı tez çalışmasından üretilmiştir.

Makalede, ulusal ve uluslararası araştırma ve yayın etiğine uyulmuştur. Çalışmada Etik Kurul izni gerekmemiştir.

\section{Kaynaklar}

Aru, K. A. (1965). Yayalar Taşıtlar: Kent Dokusunda Yeni Ulaştırma Düzenleri. iTÜ Mimarlık Fakültesi Yayınları. 
Çalışkan, M. (2011). Kamu Yararı Bağlamında Kamusal Mekânlarda Bir Yayalaştırma Örneği: Eminönü Tarihi Yarımada (Hobyar Mahallesi ve Çevresi) Yayalaştırma Projesi. (Yüksek Lisans Tezi), İstanbul Teknik Üniversitesi, Fen Bilimleri Enstitüsü, , İstanbul.

Demir, Ü. (2008). Peyzaj Tasarımında Yaya Bölgeleri Antakya Hürriyet Caddesi Yayalaştırma Örneği. (Yüksek Lisans Tezi). Fen Bilimleri Enstitüsü Peyzaj Mimarlığı Anabilim Dalı. Hatay/Antakya.

Döllük, G. (2005). Yayalaştırılmış Sokakların Kent Peyzajına Katkısı: 58. Bulvar ve İstiklal Caddesi Örneği. (Doktora Tezi), İstanbul Teknik Üniversitesi, Fen Bilimleri Enstitüsü, Peyzaj Mimarlığı Anabilim Dalı, İstanbul.

Gültekin, B. (2007). Kent İçi Yolların, Yaya Kullanımına Yönelik Değerlendirilmesinde Çözümlemeli Bir Yaklaşım: Adana Örneği. (Yüksek Lisans Tezi). Çukurova Üniversitesi Fen Bilimleri Enstitüsü Peyzaj Mimarlığı Anabilim Dalı, Adana.

Kaplan, H. ve Acuner, A. (2005). Ankara'da Yayalaştırma Sorunsalı: Yaya Alanlarının Yasal Çerçeve ve Yerel Yönetimlerin Rolü Kapsamında Değerlendirilmesi. Planlama, TMMOB Şehir Plancıları Odası Yayını, 4, 112-123.

Kuntay, O. (1994). Yaya Mekanı. Ayıntap Yayıncılık, 170.

Rubenstein, H. M. (1992). Pedestrian Malls, Streetscapes And Urban Spaces. A.B.D.: John Wiley \& Sons.

Şenkaynak, P. (2010). Yaya Bölgelerinin Kentsel Peyzaj Planlama Açısından Önemi ve İstanbul" daki Bazı Örneklerin İncelenmesi. (Yüksek Lisans Tezi), İstanbul Teknik Üniversitesi Fen Bilimleri Enstitüsü, Peyzaj Mimarlığı Anabilim Dalı, İstanbul.

Yıldız, Y .T. (2011). Isparta Ilinde Íklim-Tarım Iliş̧kisi. (Yüksek Lisans Tezi), Afyon Kocatepe Üniversitesi Sosyal Bilimler Enstitüsü Coğrafya Anabilim Dalı.

Zafer, B. (1998). Aydın Germencik Belediyesi Yaya Bölgesi Tasarımı Üzerine Bir Araştırma. Ekoloji Dergisi, (26), 27-30, izmir. 